\title{
Application of morphometric study to discriminate Pteridium aquilinum (L.) Kuhn subsp. pinetorum (C. N. Page \& R. R. Mill 1995) J. A. Thomson in Poland
}

\author{
Elżbieta Zenkteler ${ }^{1 *} \&$ Oskar Nowak ${ }^{2}$
}

\begin{abstract}
${ }^{1}$ Department of General Botany, Institute of Experimental Biology, Faculty of Biology, Adam Mickiewicz University, Uniwersytetu Poznańskiego 6, 61-614 Poznań, Poland; ORCID: EZ http://orcid.org/0000-0002-8514-4825

${ }^{2}$ Department of Human Evolutionary Biology, Institute of Human Biology and Evolution, Faculty of Biology, Adam Mickiewicz University, Uniwersytetu Poznańskiego 6, 61-614 Poznań, Poland; ORCID: ON http://orcid.org/0000-0003-1215-3226

*corresponding author (e-mail: elzbieta.zenkteler@amu.edu.pl)
\end{abstract}

\begin{abstract}
Pteridium aquilinum subsp. pinetorum is one of two morphologically distinct taxa of the genus Pteridium identified in Poland. In order to confirm their distinctively recognizable morphology, nine features defining each of these taxa were subjected to a morphometric analysis. These features, including taxonomic characters of vegetative structures, were measured or counted for their most comprehensive descriptions. The measurements were also expressed as ratios of two characters (length of the first and second pairs of leaflets) to prevent the size of fronds from influencing the results. Unique features of bracken, such as: frond and pinnae shape and orientation; basal pinna structure; ultimate segment of pinnae and pinnula shape and size; frond expansion sequencing; frond lamina texture, shape and pubescence were treated descriptively. Canonical discriminant analysis was employed for a morphometric study of quantitative characters. On their basis, two taxa - P. aquilinum subsp. aquilinum and $P$. a. subsp. pinetorum were determined.
\end{abstract}

Key words: Pteridium, morphometric study, canonical discriminant analysis

\section{Introduction}

The genus Pteridium is said to have the largest cosmopolitan distribution, occurring both in temperate and tropical regions of the world. Its main member, Pteridium aquilinum (L.) Kuhn, is considered as a multivariety complex comprising several closely related taxa. In Eurasia, $P$. aquilinum can be further subdivided into subsp. aquilinum occurring in Africa, Europe and Asia Minor and subsp. japonicum (Nakai) Á. Löve \& D. Löve - occurring from East Asia to eastern Europe (Zhou et al. 2014). Formerly, according to Tryon (1941), Pteridium aquilinum aggr. contained 2 subspecies and 12 varieties. Revisionary concepts focused on morphological, phenological and ecological criteria of $P$. aquilinum aggr. in Britain (Page 1976; Rumsey et al. 1991) and, later, in Europe resulted in the identification of two morphotypes: 'tall' aquilinum and 'small' latiusculum (Thomson 2004, 2008). Subsequently, morphotype latiusculum was given the status of a subspecies - P. pinetorum ssp. pinetorum (Page 1976, 1986, 1989), and in 1997, raised to the rank of species $-P$. pinetorum, as being worthy of nomenclatural distinction (Page 1997). The papers of Page (Page \& Mill 1995a, 1995b) are the main sources of data concerning taxonomy, distribution and ecology of $P$. pinetorum in Europe. Unfortunately, some British pteridologists remain doubtful whether $P$. pinetorum should be considered a species (Wolf et al. 1995). In response to those concerns, Thomson (2004) published a detailed comparative diagnostic description of $P$. $a$. subsp. pinetorum. Although the origin of $P$. $a$. subsp. pinetorum, native to continental Europe and Western Asia, remains still insufficiently examined, analyses of global chloroplast DNA sequences performed to determine patterns of genetic differentiation classified them as two separate elements inside this aggregate (Der et al. 2009). The authors indicated three haplotypes (A, B and $\mathrm{C}$ ) that differed with respect to nucleotide sites, in the trnS-rpS4 spacer+gene and in the rpL16 intron. They stated that $P$. a. subsp. pinetorum belonged to haplotype 
A and P.a. subsp. aquilinum - to haplotype B (Der et al. 2009). New phylogenetic analyses and species delimitation tests based on three chloroplast DNA fragments (rps4-trnSGGA, rpl16 and trnSGCU - trnGUCC) and three microsatellite loci were used to recognize again intra-clade structure of P. aquilinum. The species was divided into subsp. aquilinum (Africa, Europe and Asia Minor) and subsp. japonicum (East Asia (China, Japan, Korea, Far East of Russia/Siberia); eastern Europe (Ukraine) and northern Europe (Finland, Scotland) (Zhou et al. 2014). The results also confirmed that the subspecies $P$. aquilinum subsp. japonicum and P. aquilinum subsp. pinetorum should be treated as the same taxon. One of the recent papers concerning relationships in the genus Pteridium (Wolf et al. 2019), shows elements of genetic similarity between subsp. pinetorum and subsp. japonicum based on the ddRADseq data.

Lack of evident diagnostic features made it hard to distinguish $P$. aquilinum subsp. pinetorum from P. aquilinum in Poland. Therefore, P. aquilinum (L.) Kuhn was, so far, the only species according to data comprised in Polish Plants Checklist (Mirek et al. 2002), as well as in monograph of Rutkowski (2004). Although, when Polish authors recognised morphological differences between fronds of two peculiar populations of Pteridium, they assigned these differences to detrimental influence of heavy metal ions $(\mathrm{Cr} ; \mathrm{Pb}$; $\mathrm{Ni}$ ) contained in serpentinite soil in which one of the compared populations was growing (Halarewicz \& Koszelnik-Leszek 2007).

P. pinetorum C. N. Page \& R. R. Mill was identified, for a long time, in pteridoflora of neighbouring countries such as Russia (Shorina \& Perestronina 2000; Gureyeva \& Page 2005, 2008a, 2008b), Belarus (Tikhomirov 2009), Ukraine (Washeka \& Bezsmertna 2012), Germany (Frank 2008 as P. a. subsp. pinetorum), Czech Republic (Petřík et al. 2009) and Scandinavia (Harmaja 1990; Karlsson 2000). Preliminary studies of fresh fronds of Pteridium specimens left little doubt that two taxa occurred in Poland (Zenkteler et al. 2015). Both our native ferns became a significant component of plant associations (such as Vaccinio-Piceeta Br.-Bl. 1939 or Pruno-Rubion fruticosi R.Tx. 1952 corr. Doing $1962 \mathrm{em}$.) currently identified as part of Poland's vegetation. Whilst $P$. aquilinum subsp. aquilinum is a common taxon found in every suitable habitat, $P$. $a$. subsp. pinetorum also has a wide distribution throughout the lowland of the country (Zenkteler et al. 2015, 2016). Both taxa became widespread from dominant vegetation types of pine forests and acid grasslands.

It was clear that morphological comparison of leaves of both taxa in herbarium sheets seemed easy (P. a. subsp. pinetorum with triangular blade, smaller than oval blade of $P$. $a$. subsp. aquilinum), but it was not so obvious which qualitative and quantitative characters would be sufficient in the natural stands to determine without doubt that appropriate specimens of $P$. pinetorum were found. Therefore, it was important to investigate, examine and describe features enabling accurate diagnosis of native populations of $P$. $a$. subsp. pinetorum.

\section{Material and methods}

\subsection{Plant material}

Frond samples were collected from ten different populations of Western bracken fern (Pteridium Kuhn) across forest districts of Oborniki, Chodzież and Piła in the Wielkopolska region. Their habitats were scattered in the forest areas located about $1 \mathrm{~km}$ from the road No. 11, along the both sides of the road. In order to select some features useful to distinguish between the two Pteridium taxa, macromorphology of fronds was examined in situ and ex situ in the laboratory of Department of General Botany, also under binocular, with the aim to estimate their details. The samples were later deposited in the Herbarium of Adam Mickiewicz University in Poznań (POZ).

In total, nine quantitative characters of fronds as well as their measure units were evaluated (Table 1). These characters were chosen on the basis of literature from comprehensive description of Pteridium (Gureyeva \& Page 2005, 2008a, 2008b; Thomson et al. 2008; Thomson 2008; Tikhomirov 2009).

Quantitative characters were measured on at least 30 fronds collected from one locality, as follows: blade length (LB) was assessed along the rachis, from the top part of lamina to the base of the first pair of pinnae; stipe length (LS) was assessed from the base of the first pair of pinnae to soil level; lowermost pinnae length (LP-1) was assessed along the whole pinnae rachis; length of the second pair of pinnae (LP-2) was assessed in similar way; lowermost pinnae width (WP-1) and the second pair of pinnae (WP-2) were measured crosswise of pinnae rachis. Occurrences of pinnae pairs of the lamina (NP) were counted along the main rachis. Pinnae dissection (PD) was assessed visually. The angle between the main leaf rachis and the rachis of the second pair of pinnae (PA) was measured by a protractor.

As the analyzed material was collected from field sites, variation included environmental components. Therefore, soil samples (of at least $0.5 \mathrm{~kg}$ ) were collected from each of the teen Pteridium stands and analysed in the local Soil Laboratory of Chemical and Agricultural Station (O.S.Ch.R.) in Poznań.

\subsection{Data analysis}

The data of morphometric evaluation was gathered in a matrix containing quantitative characters and analysed 
Table 1. List of quantitative characters of Pteridium fronds used in morphometric analysis with respective acronyms and measurement units

\begin{tabular}{clcc}
\hline No & Characters & Acronym & Unit \\
\hline 1 & Length of the blade & LB & $\mathrm{cm}$ \\
2 & Length of the stipe & LS & $\mathrm{cm}$ \\
3 & Length of the lowermost pinnae & LP-1 & $\mathrm{cm}$ \\
4 & Length of the second pair of pinnae & LP-2 & $\mathrm{cm}$ \\
5 & Width of the lowermost pinnae & WP-1 & $\mathrm{cm}$ \\
6 & Width of the second pair of pinnae & WP-2 & $\mathrm{cm}$ \\
7 & Number of pinnae pairs of the lamina & NP & - \\
8 & Pinnae dissection & PD & - \\
9 & Pinnae at an acute/right angle & PA & 0 \\
\hline
\end{tabular}

by multivariate statistical analysis using the integrated system of Statistica (StatSoft 2003). The results made it possible to employ canonical discriminant analysis. Before the analysis, quantitative data were standardized. The analysis allowed determination of quantitative characters which would serve best in discrimination of the two examined Pteridium taxa.

\section{Results}

\subsection{Comparison of morphological data}

$P$. a. subsp. pinetorum were recorded from the Wielkopolska region from populations scattered from the Oborniki forest district to Piła forest district (Zenkteler et al 2015). Seven visited populations belonging to $P$. a. subsp. pinetorum were found in the areas of pinewood vegetation in a wide range of plant communities. They often occurred in dense or sparse stands in open areas; in rows along roadsides. Three populations of $P$. a. subsp. aquilinum were recorded from mesic broadleaves to coniferous forest site types. Distribution of some recent localities of $P$. $a$. subsp. pinetorum is shown in Fig. 1.

P. a. subsp. pinetorum is lower growing, with horizontally inclined fronds, where more light penetrated allowing co-habitation with grasses, mosses and other species associated with pinewood communities (Fig. 2a, 2b). Stipe was short 29-91 cm, erect, rigid, with blade ascending horizontally. Blade was broadly triangular, $35-98 \mathrm{~cm}$ in length, bipinnate, bright green in colour on the upper surface. The number of pinnae on rachis

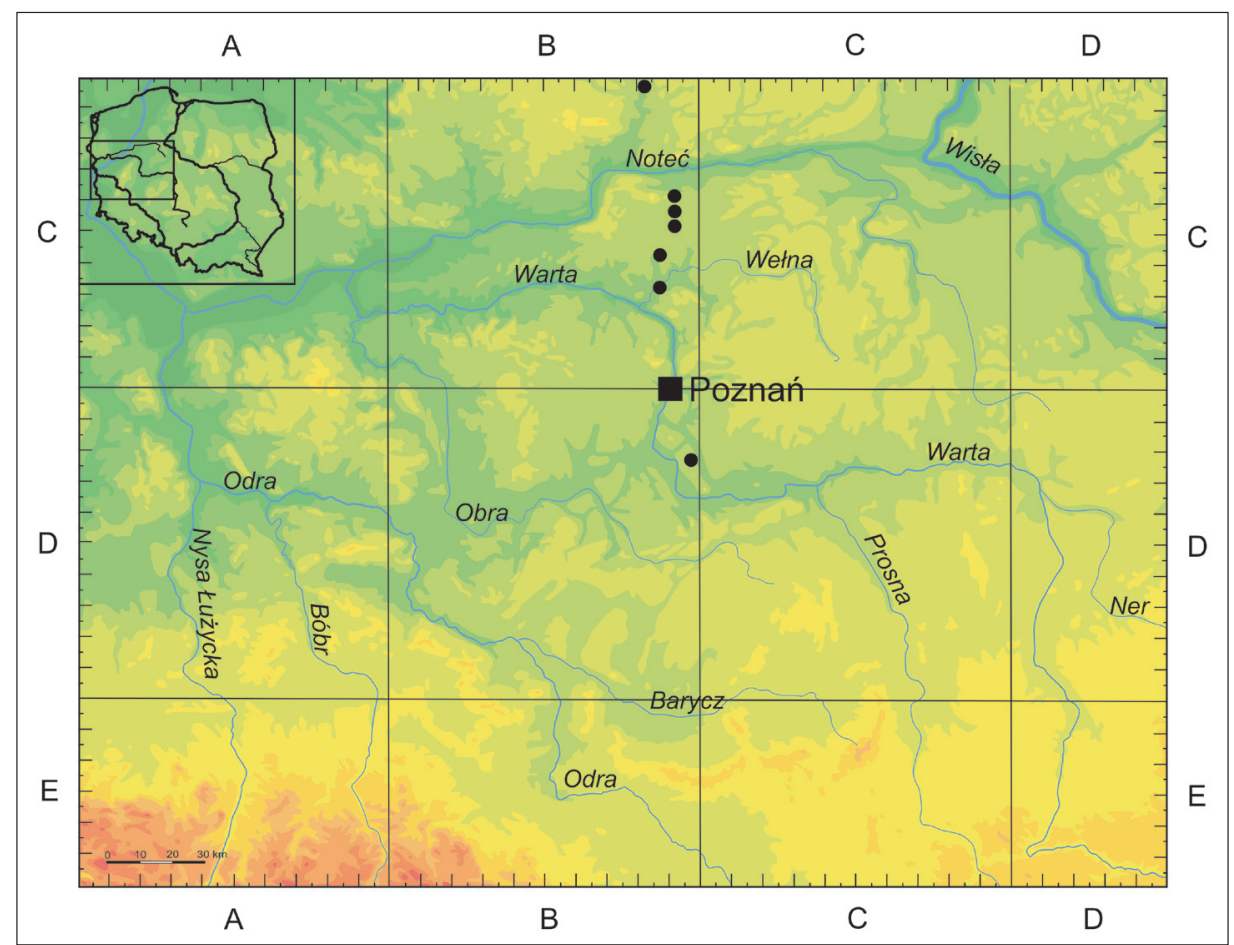

Fig. 1. Distribution map of natural localities of Pteridium aquilinum subsp. pinetorum in the Wielkopolska region 

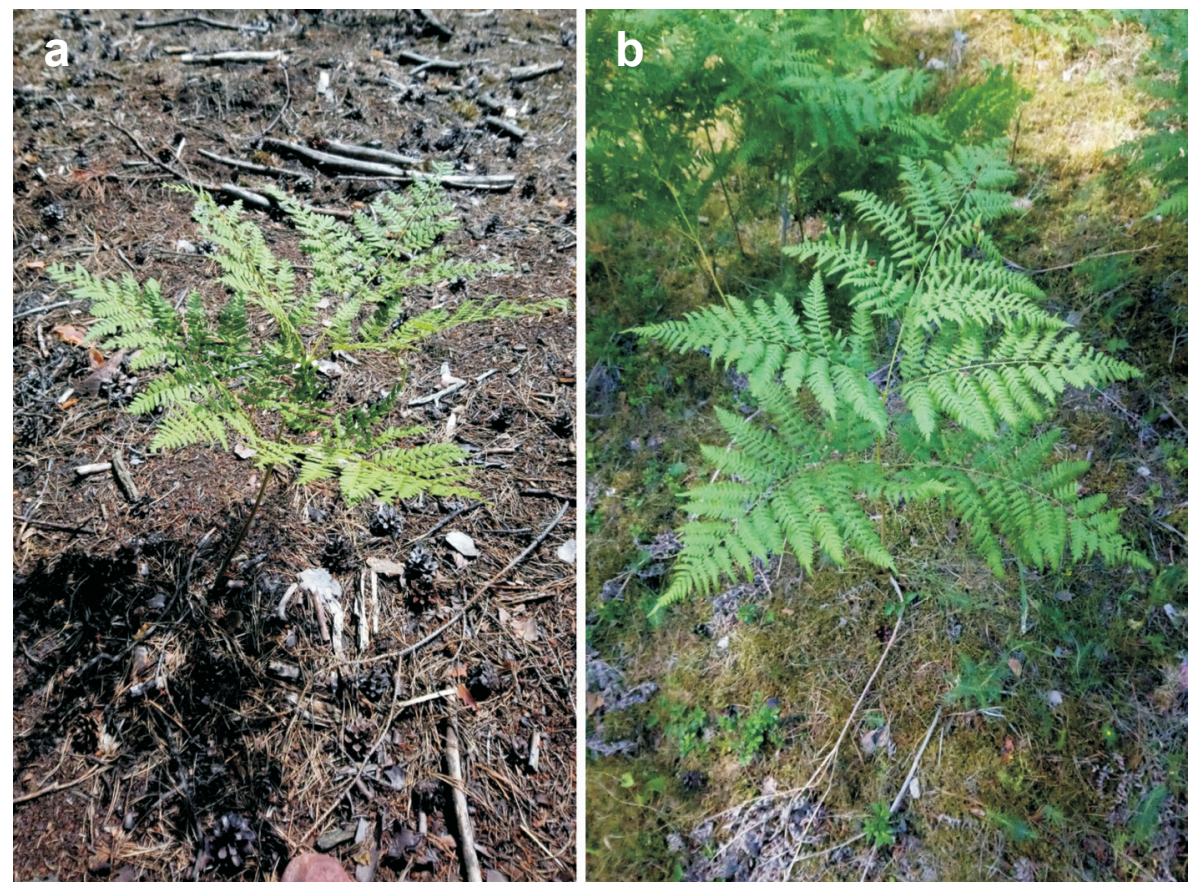

Fig. 2. Habit of Pteridium aquilinum subsp. pinetorum in the studied localities in pine forest (a) and along a forest road (b) (photograph by K. Michalak)

was $6-13$, the basal half-length of the first pinna 24$54 \mathrm{~cm}$ and respective width $17-40 \mathrm{~cm}$. The length of the second pinnae pair was $16-46 \mathrm{~cm}$ and respective width $15-34 \mathrm{~cm}$. In autumn, fronds turned yellow-brown. The distinctive features of this subspecies included: rapid frond development rate in spring and the proportion of the length of the first pair of pinnae I-r to the smaller second pair, stiff and rigid fronds, rapid whole-frond expansion rate and triangular shape of blades.

Widespread and cosmopolitan P. a. subsp. aquilinum is a much larger and taller-growing taxon with vigorous and highly variable fronds, occurring frequently in mixed forests (Fig. 3a, 3b). Its distinctive characteristics included: slow frond expansion rate, soft frond texture
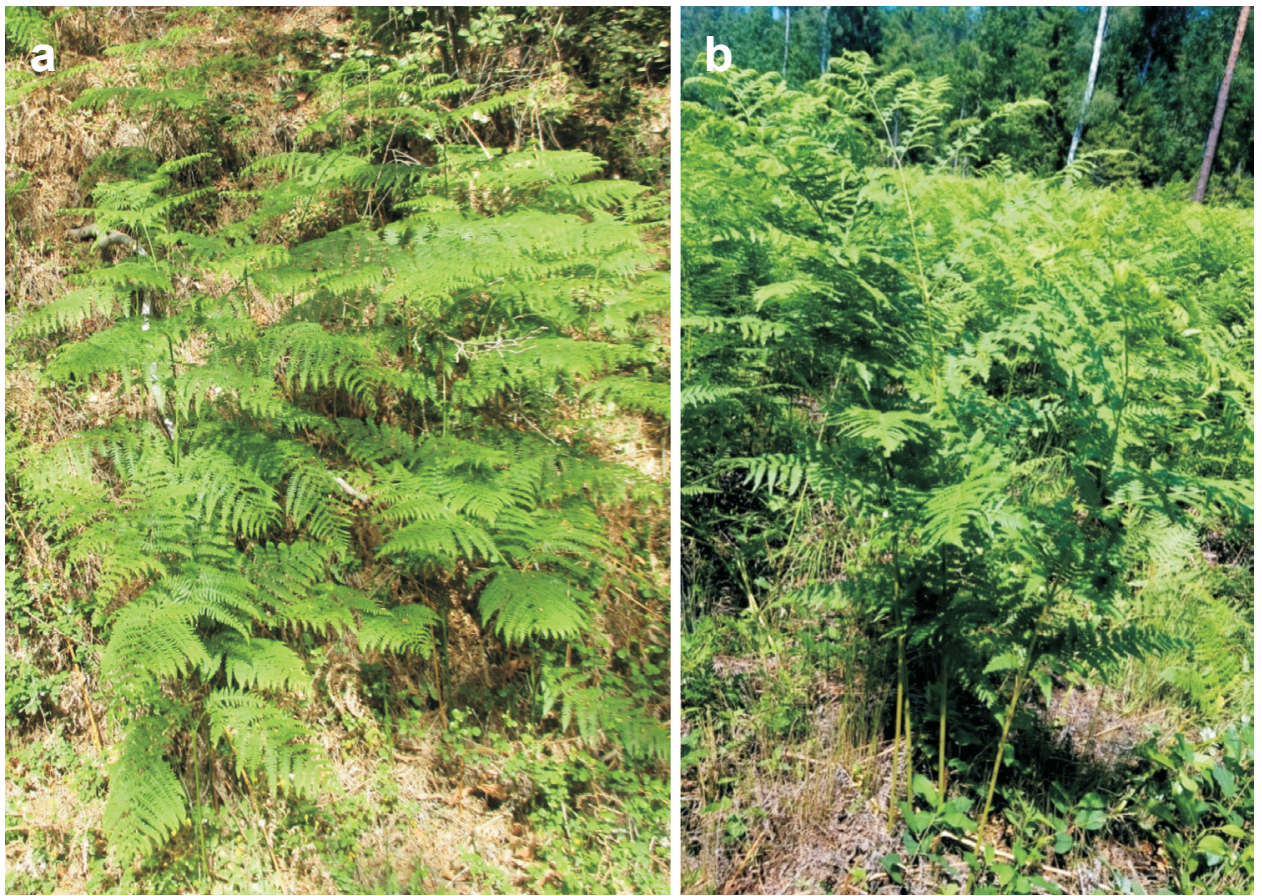

Fig. 3. Pteridium aquilinum subsp. aquilinum on the slope inside a broad-leaved forest (a) and on the forest edge (b) (photograph by E. Zenkteler and K. Michalak) 
Table 2. Two Pteridium taxa delimitation based on their diagnostic characters in natural localities

\begin{tabular}{ll}
\hline \multicolumn{1}{c}{ P. a. subsp. pinetorum } & \multicolumn{1}{c}{ P. a. subsp. aquilinum } \\
\hline Straw frond lamina & Leathery frond lamina \\
Rachis arcuate & Rachis upright \\
The first pair of pinnae are the longest & The second pair of pinnae are the longest \\
Pinnules ovate on stipites & Pinnules elongate, sessile \\
Pinnulets rounded at apex & Pinnulets acute at apex \\
Pinnae dissection 2 & Pinnae dissection 2-3 (rare 3-4) \\
Glabrous, sparse, short, catenate hairs & Pubescent, with long, catenate hairs \\
Pseudo-indusium narrow & Pseudo-indusium vide \\
Acute angle between rachis and pinnae & Right angle joined pinna to rachis \\
Frond expansion 1-2 weeks & Frond expansion 3-4 weeks \\
Average frond density 6-10 $\mathrm{m}^{2}$ & Average frond density 10-15 $\mathrm{m}^{2}$ \\
\hline
\end{tabular}

and late seasonality. Stipe was $39-94 \mathrm{~cm}$ in length, erect, rigid, with blade raised vertically. Blade was oval-oblong, 60-191 cm in length, bi-, three-pinnate (2-3), dark green in colour on the surface. The number of pinnae on rachis was 8-17 and they were deflected at the top. The length of the first pinnae pair was $26-58 \mathrm{~cm}$ and respective width $16-34 \mathrm{~cm}$. The length of the second pinnae pair was $30-70 \mathrm{~cm}$ and respective width 26-39 $\mathrm{cm}$. Further distinctive features of P. a. subsp. aquilinum included: vertical orientation of the rachis with horizontally inserted pinnae and tight, unrolling pinna pairs during gradual development (Table 2; Fig. 3a, 3b). The indumentum of $P$. $a$. subsp. aquilinum was characterized by abundant, cinnamon-coloured hairs covering croziers at the beginning of the expansion phase (Fig. 4a). At the same time, the top of expanding lamina of $P$. $a$. subsp. pinetorum was covered by light-coloured hairs (Fig. $4 \mathrm{~b}$ ). The results of fronds comparison and their spring development rates provided evidence of morphological differences in form and phenology between the two taxa of bracken (Table 2).

Samples, that represented 'true' morphotypes of both: $P$. a. ssp. pinetorum and $P$. a. subsp. aquilinum were morphologically different during comparison of herbarium specimens (Fig. 5). Their characters revealed all features taken into account as diagnostic for the two taxa. As can be seen in Fig. $2 b$ and $3 b$, stipe and blade in P. a. subsp. pinetorum were shorter than in P. $a$. subsp. aquilinum. The arrangement of pinna I-row and the number of side pinnae pairs were less numerous in
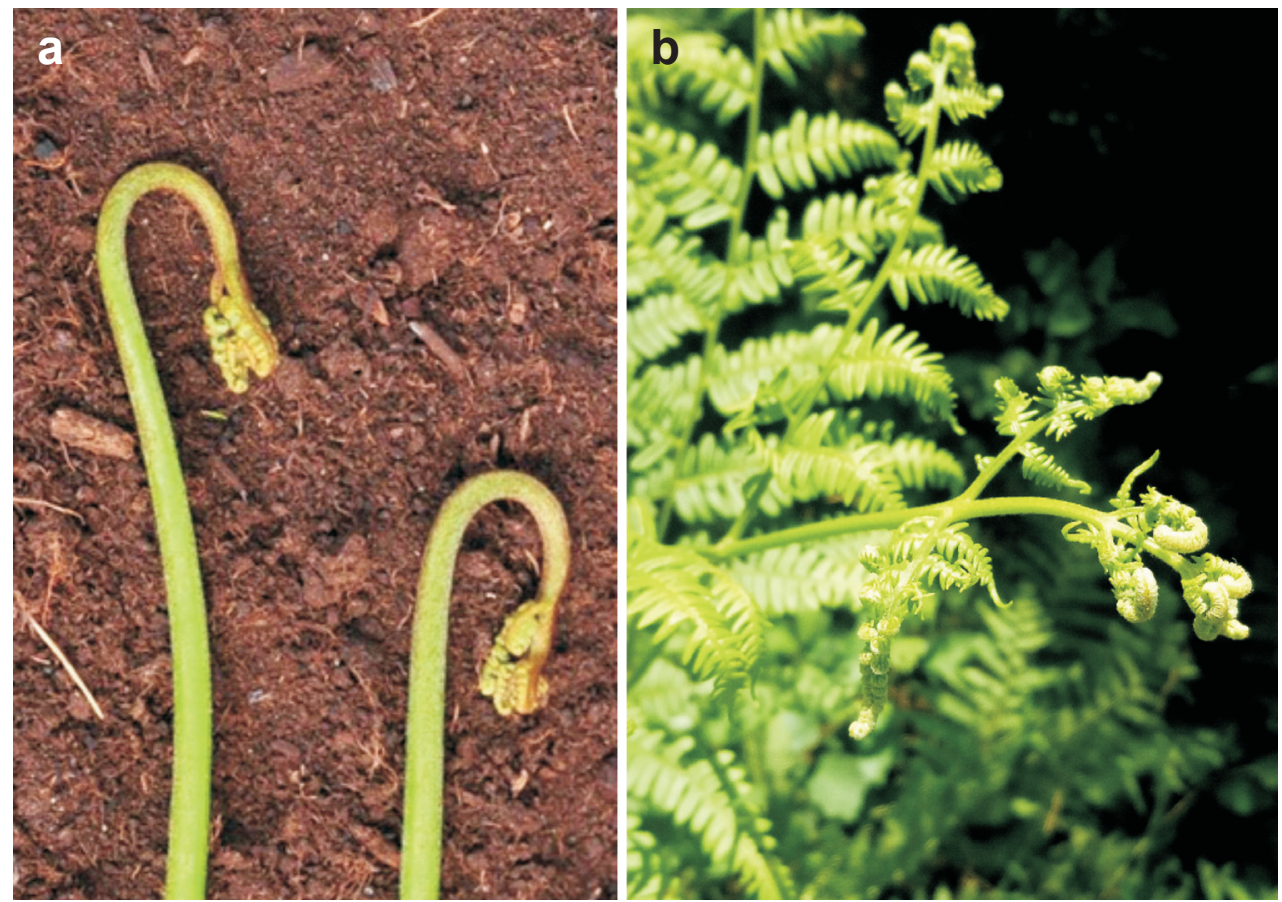

Fig. 4. Indumentum (hairy coat) of (a) croziers of Pteridium aquilinum subsp. pinetorum and (b) young leaves of Pteridium aquilinum subsp. aquilinum (photograph by E. Zenkteler) 

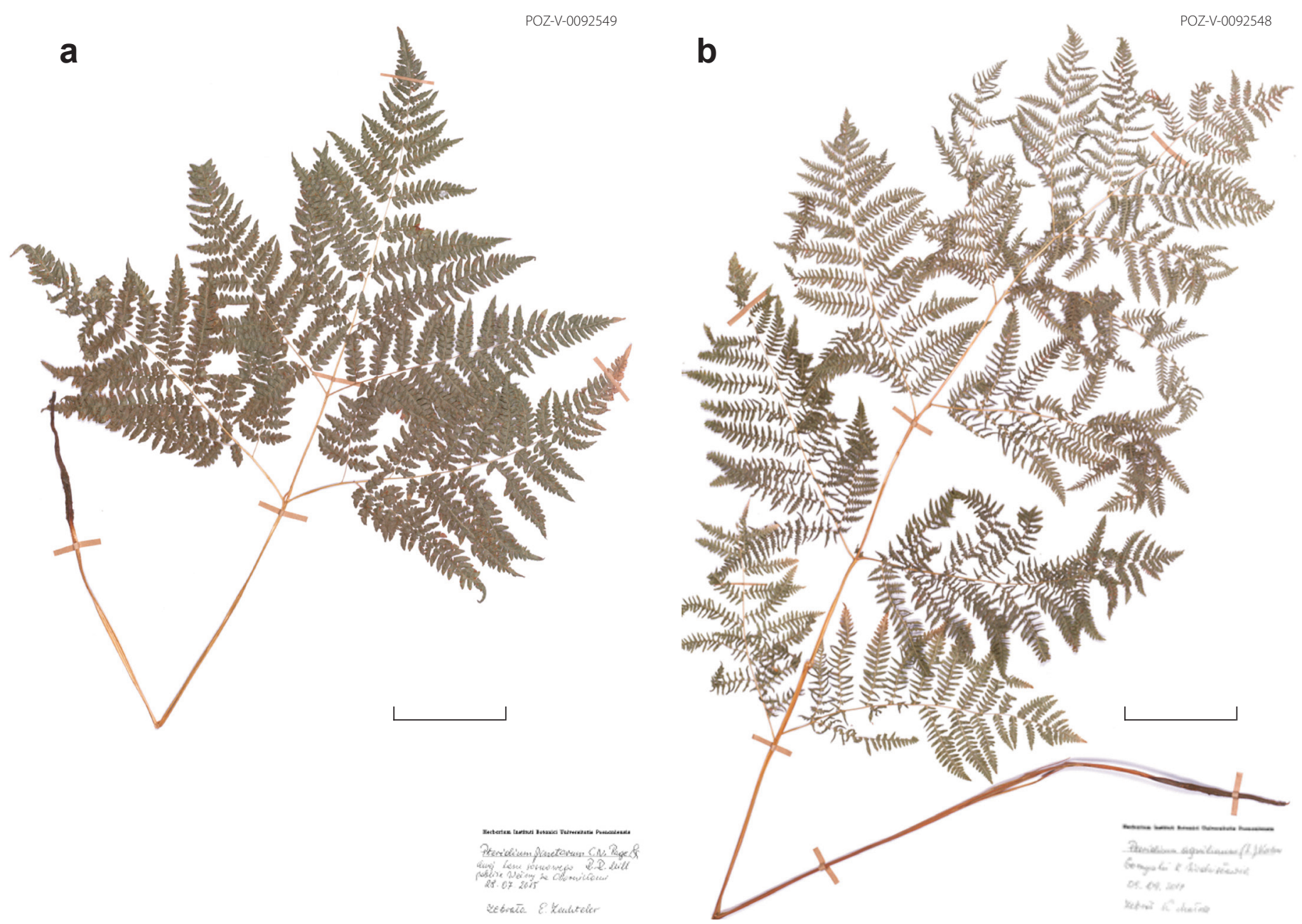

Fig. 5. Comparison of size. shape and lamina structure of fronds of: (a) Pteridium aquilinum subsp. pinetorum and (b) Pteridium aquilinum subsp. aquilinum specimens, collected from the Wielkopolska region and deposited in the Herbarium of Adam Mickiewicz University in Poznań (POZ). Scale bars $-10 \mathrm{~cm}$

P. a. subsp. pinetorum than in $P$. a. subsp. aquilinum (Fig. 5a and 5b). Morphological characters of fronds that were of taxonomic value differed remarkably in
P. a. subsp. pinetorum and P. a. subsp. aquilinum. Generally, fronds of $P$. $a$. subsp. pinetorum showed smaller amount of variation of blade structure contrary to $P$. $a$.

Table 3. Nutrient level of soil samples collected from natural localities of two Pteridium taxa

\begin{tabular}{|c|c|c|c|c|c|c|c|c|}
\hline \multirow{2}{*}{$\begin{array}{c}\text { No of } \\
\text { sample }\end{array}$} & \multirow{2}{*}{$\mathrm{pH}$} & \multicolumn{6}{|c|}{ Contents $\mathrm{mg} / \mathrm{dm}^{3}$ of soil } & \multirow{2}{*}{$\mathrm{NaCl} g / \mathrm{dm}^{3}$} \\
\hline & & $\mathrm{N}-\mathrm{NO}_{3}$ & $\mathrm{P}$ & $\mathrm{K}$ & $\mathrm{Ca}$ & $\mathrm{Mg}$ & $\mathrm{Cl}$ & \\
\hline 1 & 3.6 & 4 & $<2.7$ & 25 & 123 & 23 & $<11.5$ & 0.07 \\
\hline 2 & 3.7 & 10 & 15 & 25 & 225 & 45 & 17 & 0.24 \\
\hline 3 & 4.2 & $<2.8$ & 4 & 30 & 163 & 41 & $<11.5$ & 0.07 \\
\hline 4 & 4.5 & 3 & $<2.7$ & 25 & 123 & 28 & $<11.5$ & 0.06 \\
\hline 5 & 4.7 & 74 & 7 & 115 & 357 & 104 & $<11.5$ & 0.54 \\
\hline 6 & 5.2 & 4 & 7 & 50 & 286 & 71 & 12 & 0.11 \\
\hline 7 & 3.8 & 16 & 15 & 40 & 153 & 41 & $<11.5$ & 0.23 \\
\hline 8 & 4.4 & 50 & 20 & 55 & 429 & 121 & $<11.5$ & 0.37 \\
\hline 9 & 4.1 & 38 & 11 & 20 & 276 & 34 & $<11.5$ & 0.24 \\
\hline 10 & 3.5 & 15 & 11 & 18 & 223 & 25 & $<11.5$ & 0.29 \\
\hline Means & 4.1 & 21.7 & 9.5 & 40.3 & 235.8 & 53.3 & 12.1 & 0.22 \\
\hline
\end{tabular}

Explanation: samples from the localities of Pteridium aquilinum subsp. aquilinum $(5,7,9)$ and Pteridium aquilinum subsp. pinetorum $(1,2,3,4,6,8,10)$ 
Table 4. T-test of differences in morphological characters of the fronds of Pteridium aquilinum subsp. pinetorum (Pp) and Pteridium aquilinum subsp. aquilinum $(\mathrm{Pa})$

\begin{tabular}{lrrrrr}
\hline Variable & Mean & Std. deviation & t-value & df & p \\
\hline LB_Pp & $\mathbf{5 4 . 5 8}$ & $\mathbf{1 4 . 6 7}$ & & & \\
LB_Pa & $\mathbf{1 0 1 . 1 3}$ & $\mathbf{4 0 . 7 1}$ & $\mathbf{- 5 . 3 0}$ & $\mathbf{2 5}$ & $\mathbf{0 . 0 0 0 0 1 7}$ \\
LS_Pp & $\mathbf{4 8 . 6 7}$ & $\mathbf{1 6 . 8 9}$ & & & \\
LS_Pa & $\mathbf{6 7 . 3 5}$ & $\mathbf{1 4 . 2 2}$ & $\mathbf{- 4 . 9 7}$ & $\mathbf{2 5}$ & $\mathbf{0 . 0 0 0 0 4 0}$ \\
LP 1_Pp & 38.15 & 7.78 & & & \\
LP 1_Pa & 40.95 & 7.75 & -1.60 & 25 & 0.122291 \\
LP 2_Pp & $\mathbf{3 1 . 3 4}$ & $\mathbf{7 . 6 7}$ & & & \\
LP2_Pa & $\mathbf{4 9 . 3 8}$ & $\mathbf{9 . 2 4}$ & $\mathbf{- 9 . 7 2}$ & $\mathbf{2 5}$ & $\mathbf{0 . 0 0 0 0 0 0}$ \\
WP 1_Pp & 28.72 & 5.46 & & & \\
WP 1_Pa & 27.58 & 4.60 & 0.78 & 24 & 0.443473 \\
WP 2_Pp & $\mathbf{2 4 . 6 2}$ & $\mathbf{5 . 0 0}$ & & & \\
WP 2_Pa & $\mathbf{3 3 . 3 0}$ & $\mathbf{4 . 0 4}$ & $\mathbf{- 6 . 4 0}$ & $\mathbf{2 4}$ & $\mathbf{0 . 0 0 0 0 0 1}$ \\
NP_Pp & $\mathbf{8 . 9 2}$ & $\mathbf{1 . 2 2}$ & & & \\
NP_Pa & $\mathbf{1 2 . 4 0}$ & $\mathbf{2 . 3 8}$ & $\mathbf{- 6 . 4 2}$ & $\mathbf{2 4}$ & $\mathbf{0 . 0 0 0 0 0 1}$ \\
PD Pp & 2.48 & 0.51 & & & \\
PD Pa & 2.61 & 0.50 & $\mathbf{- 0 . 9 0}$ & 22 & 0.377440 \\
PA_Pp & $\mathbf{3 7 . 6 0}$ & $\mathbf{8 . 2 5}$ & & & \\
PA_Pa & $\mathbf{5 0 . 2 0}$ & $\mathbf{5 . 4 9}$ & $\mathbf{- 6 . 6 7}$ & $\mathbf{2 4}$ & $\mathbf{0 . 0 0 0 0 0 1}$ \\
\hline
\end{tabular}

subsp. aquilinum, with great irregularity in the size and number of pinnae of I-row.

Field observations of $P$. $a$. subsp. pinetorum showed that the taxon preferred open areas, where competition of other plants was low, and it was rather absent in dense stands. In open conditions, their short fronds produced spores more often. In the summer of 2016, both subspecies of ferns were observed to be sterile; however, their leaves reached maturity. This study also supports in situ observation of the rate of spring development of both taxa. Although restricted to material from the area of Wielkopolska, the present study

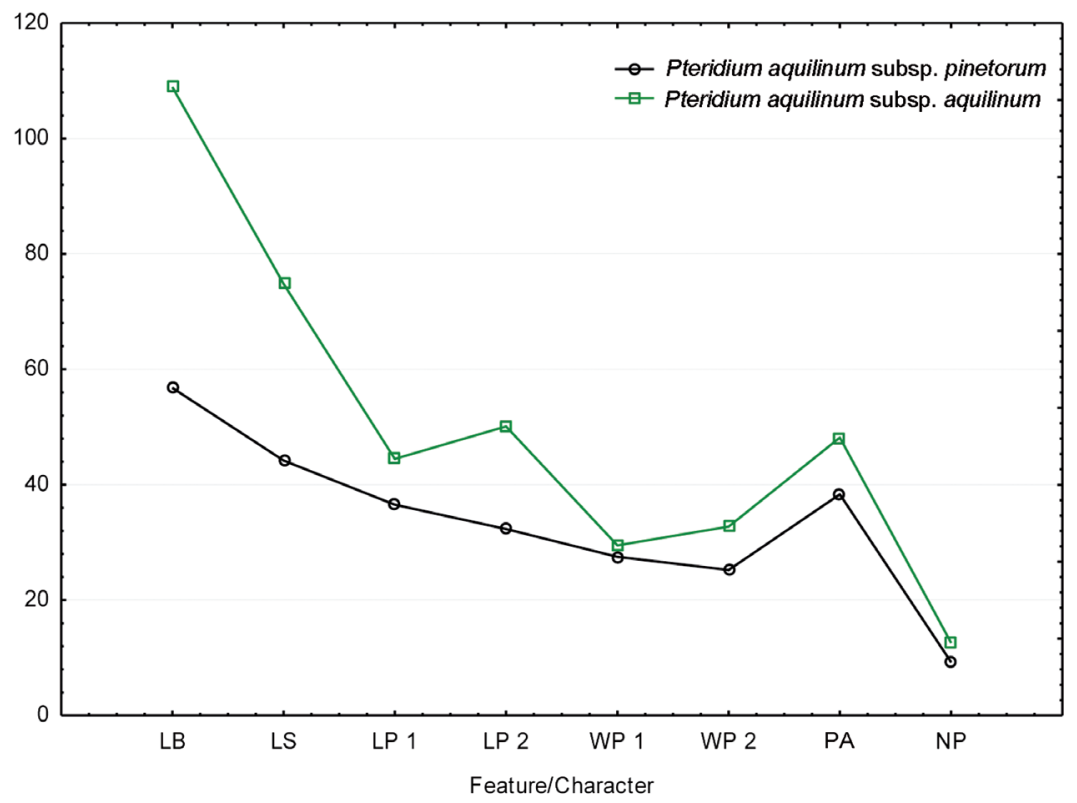

Fig. 6. Diagram of the mean values of the morphometric measurements in two studied taxa 
Table 5. Results of discriminant function multivariate analysis of variance (MANOVA)

\begin{tabular}{lcccccc}
\hline N=72 & $\begin{array}{c}\text { Wilks' } \\
\text { Lambda }\end{array}$ & $\begin{array}{c}\text { Partial } \\
\text { Lambda }\end{array}$ & $\begin{array}{c}\text { F remove } \\
(1.62)\end{array}$ & p-level & Toler. & $\begin{array}{c}\text { 1-Toler. } \\
\text { (R-sqr.) }\end{array}$ \\
\hline LB & 0.115089 & 0.991090 & 0.55739 & 0.458135 & 0.333184 & 0.666816 \\
LS & 0.115796 & 0.985037 & 0.94178 & 0.335591 & 0.814629 & 0.185371 \\
LP 1 & 0.119778 & 0.952292 & 3.10609 & 0.082929 & 0.215849 & 0.784152 \\
LP 2 & $\mathbf{0 . 1 3 9 7 2 4}$ & $\mathbf{0 . 8 1 6 3 4 6}$ & $\mathbf{1 3 . 9 4 8 1 5}$ & $\mathbf{0 . 0 0 0 4 1 1}$ & $\mathbf{0 . 1 8 4 7 1 3}$ & $\mathbf{0 . 8 1 5 2 8 7}$ \\
WP 1 & $\mathbf{0 . 1 8 8 0 8 6}$ & $\mathbf{0 . 6 0 6 4 4 3}$ & $\mathbf{4 0 . 2 3 5 4 9}$ & $\mathbf{0 . 0 0 0 0 0 0}$ & $\mathbf{0 . 1 6 5 5 3 6}$ & $\mathbf{0 . 8 3 4 4 6 4}$ \\
WP 2 & $\mathbf{0 . 1 7 0 4 1 0}$ & $\mathbf{0 . 6 6 9 3 4 9}$ & $\mathbf{3 0 . 6 2 7 2 7}$ & $\mathbf{0 . 0 0 0 0 0 1}$ & $\mathbf{0 . 2 3 0 6 9 4}$ & $\mathbf{0 . 7 6 9 3 0 6}$ \\
NP & 0.114326 & 0.997706 & 0.14258 & 0.707020 & 0.430611 & 0.569389 \\
PD & 0.114069 & 0.999953 & 0.00294 & 0.956921 & 0.868388 & 0.131612 \\
PA & 0.121938 & 0.935420 & 4.28042 & 0.042730 & 0.893837 & 0.106164 \\
\hline
\end{tabular}

Explanations: number of variables in model: 9; Grouping: taxa (2 groups)

provides additional evidence to support the existence of two subspecies belonging to the genus Pteridium in our country (Fig. 5, Table 2).

Gradient of soil conditions assessed by chemical analysis revealed its relative low nutrient level. The soil in Pteridium localities contained sand, clay and gravel, was acidic and rather poor in nutrients (Table 3 ). Surface peaty layer (from decaying frond-blades) was narrow. Both subspecies occurred mainly on acid podzols. The localities of ten populations exhibited rather similar nutrient contents: N-21,7; P-9,5; K-40,3. Measurements of $\mathrm{pH}$ ranged from 3.5-4.7, therefore, populations of Pteridium were tolerant to a wide range of acidity. Frond heights were not very tall in poor nutrient local conditions (Table 3 ).

\subsection{Comparison of morphometric data}

This study re-examined the usefulness of morphometry to discriminate as separate two closely related taxa of the genus Pteridium. The data of morphometric measurements of the two taxa contained in Table 4 reveals differences between statistic means of nine evaluated frond characters. Statistical significance of differences in the values of frond morphometric data is visible in all cases besides characters such as: WP1 (for both subspecies) and PD (both subspecies). Diagrams of the results of T-test show differences in morphological features of fronds between the two analyzed taxa (Fig. 6). The most widely used as alternative statistics to perform a similar task to T-test is Wilks'Lambda test (Table 5). This is useful in direct measurement of the proportion of the variance in the combination of two independent variables.

Wilks' Lambda multivariate test also confirmed differences in morphology of analysed frond features. Statistical significance in different data of measured frond characters was indicated in all cases except: WP 1, WP 2 and pinnae dissection. Ordination of the fronds of Pteridium specimens by coefficient values represents the two axes. Table 6 contains standardized coefficients of discriminant function for canonical variables. On this level, two morphotypes are distinctly visible.

Table 6. Discriminant coefficients values for two analyzed subspecies

\begin{tabular}{lcc}
\hline Character & $\begin{array}{c}\mathrm{Pa} \\
\mathrm{p}=0.34722\end{array}$ & $\begin{array}{c}\mathrm{Pp} \\
\mathrm{p}=0.65278\end{array}$ \\
\hline LB & -0.0730 & -0.1098 \\
LS & 0.1424 & 0.0887 \\
LP 1 & 0.1720 & $\mathbf{0 . 5 5 1 1}$ \\
LP 2 & 0.1081 & $\mathbf{- 0 . 6 5 4 7}$ \\
WP 1 & $\mathbf{- 1 . 2 6 5 4}$ & 0.5681 \\
WP 2 & $\mathbf{2 . 0 3 2 6}$ & 0.3630 \\
NP & 3.1544 & 3.3946 \\
PD & 11.1305 & 11.2299 \\
PA & 0.7770 & 0.5186 \\
Constant & -78.0072 & -49.7622 \\
\hline
\end{tabular}

Explanations: Pa - Pteridium aquilinum subsp. aquilinum, $\mathrm{Pp}$ - Pteridium aquilinum subsp. pinetorum, coefficient values, taxa groupings 


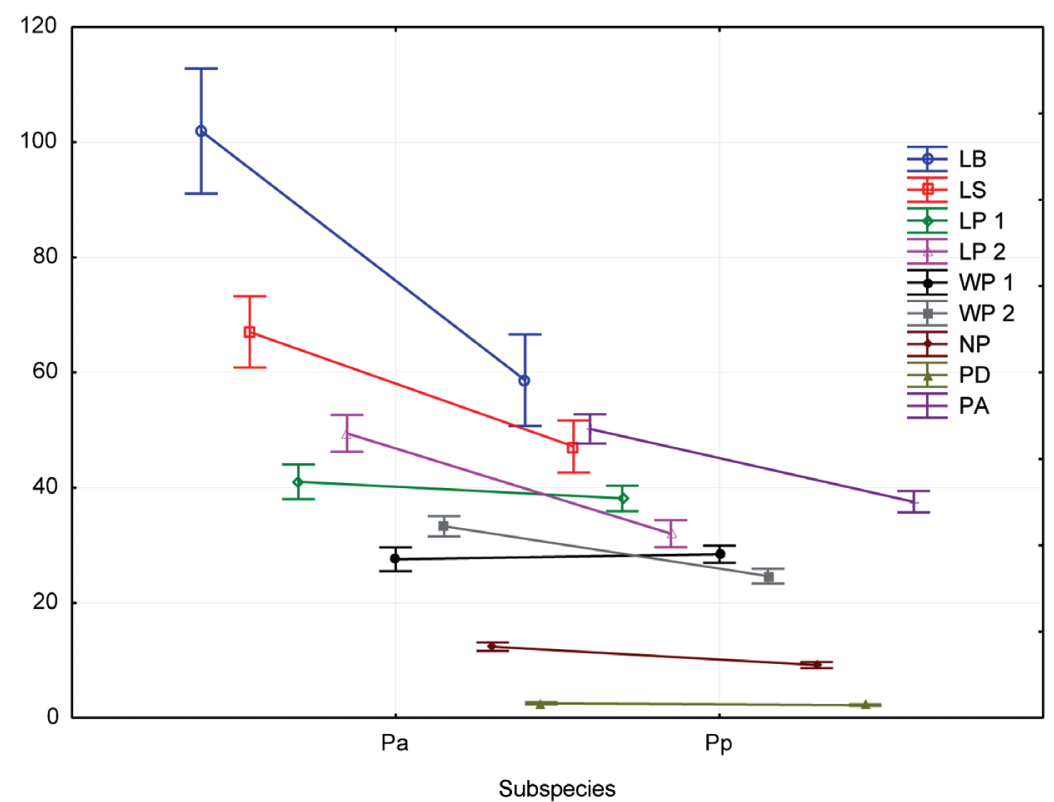

Fig. 7. Morphological characters of Pteridium aquilinum subsp. aquilinum (Pa) and Pteridium aquilinum subsp. pinetorum (Pp) analyzed using a multivariate analysis (Wilks' Lambda test)

Explanations: Wilks'Lambda $=0.11406, \mathrm{~F}(9.62)=53.506, \mathrm{p}=0.0000$. Vertical bars denote $95 \%$ confidence intervals

The results of the cluster analysis and canonical discriminant analysis of fronds support the recognition of $P$. a. subsp. aquilinum and $P$. a subsp. pinetorum as two separate taxa. The four most important features that discriminate these two specimens are: the length and width of the first and second pairs of pinnae (Fig. 7, Table 7).

Ordination of fronds of Pteridium specimens by canonical discrimination analysis was presented on two canonical axes (Table 7). This analysis revealed that population of $P$. $a$. subsp. aquilinum is evidently separated from related population of P.a. subsp. pinetorum. Eigenvalues for each canonical variable and cu- mulative proportion of explained variance were given as well.

The distribution chart of samples analysed by their morphological variability delimitated the two examined taxa. Mahalanobis distance squares were used to illustrate the distribution of samples, with each point representing one plant. Coordinates of points/ plants on the chart - Mahalanobis distance squares - made it possible to allocate each sample to an appropriate subspecies group (Fig. 8). As shown below, a distinctive segregation of $P$. $a$. ssp. pinetorum was obtained (green ellipse) and P. a. subsp. aquilinum (red ellipse).

Table 7. Raw and standardized coefficients for canonical variables

\begin{tabular}{lcc}
\hline Character & $\begin{array}{c}\text { Raw } \\
\text { coefficients }\end{array}$ & $\begin{array}{c}\text { Standardized } \\
\text { coefficients }\end{array}$ \\
\hline LB & -0.006378 & -0.173738591 \\
LS & -0.009291 & -0.143987461 \\
LP 1 & 0.065684 & 0.499482373 \\
LP 2 & $\mathbf{- 0 . 1 3 2 1 5 1}$ & $\mathbf{- 1 . 0 5 9 3 7 5 4 2}$ \\
WP 1 & $\mathbf{0 . 3 1 7 6 5 6}$ & $\mathbf{1 . 6 3 8 1 6 0 7}$ \\
WP 2 & $\mathbf{- 0 . 2 8 9 2 5 2}$ & $\mathbf{- 1 . 2 7 1 9 3 6 4}$ \\
NP & 0.041600 & 0.0775523079 \\
PD & 0.017206 & 0.00785396391 \\
PA & -0.044774 & -0.285574957 \\
Constant & 3.902285 & - \\
Eigenval. & 7.767050 & 7.76705036 \\
Cum. prop. & 1.000000 & 1.000000 \\
\hline
\end{tabular}

Explanations: values for which discriminant functions are most weighted were given in bold. Eigenvalue for each canonical variable and cumulative proportion of explained variance are included 


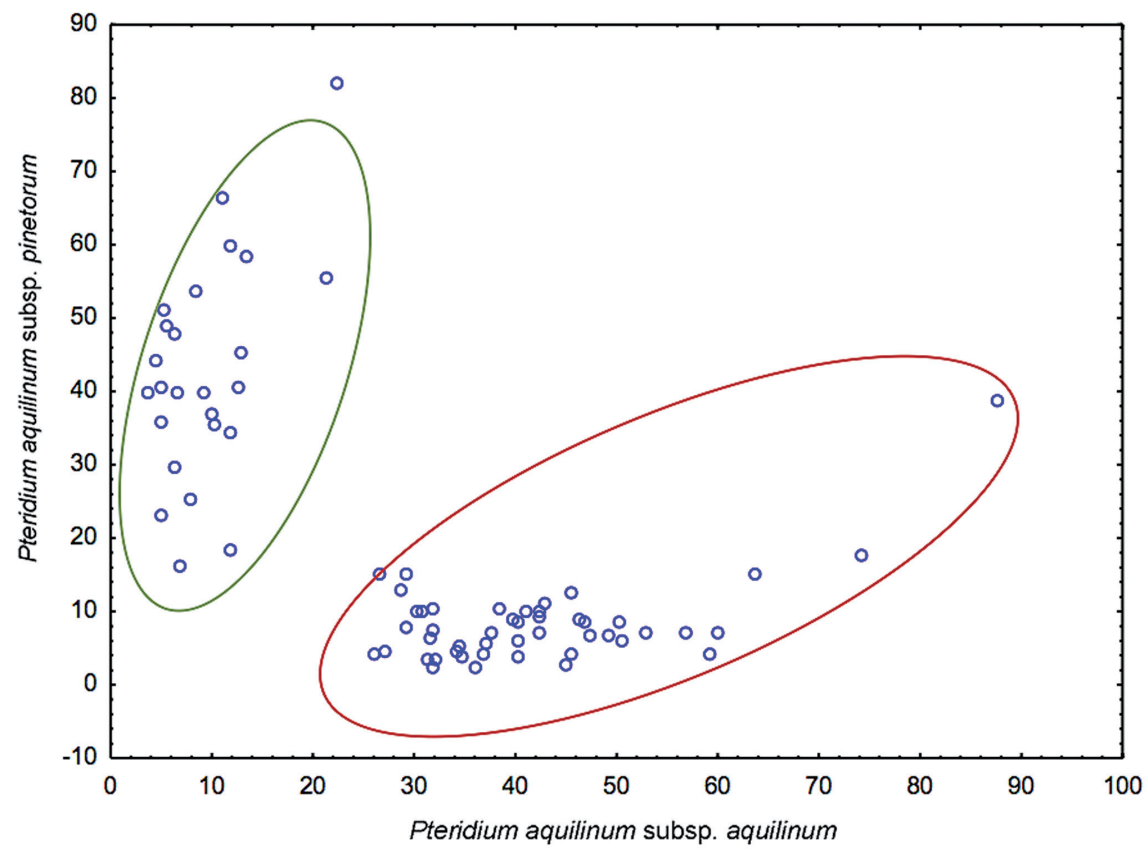

Fig. 8. Scatterplot of Mahalanobis distance squares between two analyzed taxa

\section{Discussion}

The occurrence of two taxa of bracken in Poland was not recognized so far. Considerable morphological variability of $P$. aquilinum was the main cause of discontinuance in attentive observation and perception of the distinct second taxon as $P$. a. subsp. pinetorum. This taxon was not mentioned recently in the main Polish botanical synopsis (Mirek et al 2002; Rutkowski 2004). Important justification of the fact is a remark: "The unknown are often unseen" (Frank 2008). The author, analysing the oldest herbarium specimens of Pteridium, noticed that $P$. pinetorum was formerly recorded in many locations in Germany as P. aquilinum. In Polish herbarium collections, the situation can be similar. P. $a$. subsp. pinetorum, which also occur across northern Europe (Page 1986, 1989, 1995a, 1995b); Siberia and East Asia (Gureyeva \& Page 2005, 2008a, 2008b), appears to be native to our country as an ancient member of local pteridoflora. P. a. subsp. pinetorum at its locality in the Wielkopolska region (forests in Oborniki, Chodzież and Piła districts) is vigorous, forms large populations and tends to prefer the areas of pine forest, their edges and nearby open stands. As a result of measurements and morphometric analysis, morphological differces of $P$. a. aquilinum and $P$. a. subsp. pinetorum were not only confirmed, but some useful characters to facilitate their identification were also provided (Table 2). One of them was the rate of spring development of fronds, quite useful in discrimination between the two taxa in situ. Field observations allowed the conclusion that phenotypic plasticity of fronds was greater in $P$. $a$. subsp. aquilinum than in $P$. a. subsp. pinetorum. The explanation of this phenomenon was given by Gureyeva \& Page (2008b), who noted that, in all populations of P. a. subsp. aquilinum, alongside fully developed big fronds, fronds with lesser dissection and dimension appeared, that developed later than the remaining ones (from immature croziers). Our morphometric study also revealed that morphological variability within each taxon was significantly lower than variability between them, as shown by data from Table 4 and Fig. 5 .

In this study, out of nine characters of fronds used to distinguish $P$. $a$. subsp. pinetorum. from $P$. $a$. subsp. aquilinum, the highest indicative potential was recorded in a set of four: length of the lowermost pair of pinnae (LP-1): length of the second pair of pinnae (LP-2); together with length of the stipe (LS) and the number of pinna pairs of the lamina (NP) in both compared taxa. Morphometric analysis of fronds quantitative characters proved that the two taxa could be delimited on the basis of distinction of relative low numbers of morphological characters. Among 29 quantitative characters (Thompson et al. 2008), 23 characters chosen by Gureyeva \& Page (2008a, 2008b) and 21 by Tikhomirov (2009), which were used in delimitation of Pteridium in their own papers, the most helpful were only a few: length of the basal pinna of the first and second pair of lamina segments.

In our study, the most reliable diagnostic characters were reduced to nine and they provided sufficient discriminating characters for separating the two taxa of 
bracken. According to the result of canonical discriminant analysis of both Pteridium taxa, the scatterplots of the compared samples formed two distinct clouds (Fig. 8 ) confirming our field observations and morphological comparison. Gureyeva \& Page (2008b, 2015), using discriminant analysis, also confirmed the presence of two isolated bracken subspecies (pinetorum and sibiricum) in the Euro-Siberian region.

In Polish field observations, other qualitative traits, such as colour and texture of frond lamina, are less evident because they can be affected by environmental conditions (shading or water-logging). In addition, informative value have frond terminating leaflets, which are more loose in $P$. a. subsp. aquilinum in contrast to those in $P$. $a$. subsp. pinetorum that are found together on undivided top. Moreover, according to Thomson, additional observations of high diagnostic value are: microscopic confirmation of pseudo-indusia width $(0.25$ $\mathrm{mm}$; 0.21-0.28 mm for pinetorum) and specific shape of their indusial cells (Thomson et al. 2008).
Although restricted to the material originating from the area of Wielkopolska and native to its flora, the presented results provide evidence that supports the presence of $P$. aquilinum subsp. pinetorum as a distinct subspecies in the Polish pteridoflora. The conducted research significantly expands the knowledge about the occurrence of $P$. aquilinum subsp. pinetorum in Poland.

Acknowledgements. The authors are grateful to mgr Kornel Michalak for his help in photographic documentation. We thank Dr hab. Piotr Szkudlarz and Dr hab. Zbigniew Celka for help in the preparation of scans of herbarium specimens.

\section{Author Contributions}

Research concept and design: Elżbieta Zenkteler Acquisition and/or assembly of data: Elżbieta Zenkteler Data analysis and interpretation: Oskar Nowak, Elżbieta Zenkteler

Drafting the article: Elżbieta Zenkteler

Critical revision: Elżbieta Zenkteler

Final approval: Oskar Nowak, Elżbieta Zenkteler

\section{References}

Der J. P., Thomson J. A. Stratford J. K. \& Wolf P. G. 2009. Global chloroplast phylogeny and biogeography of bracken (Pteridium; Dennstaedtiaceae). Am. J. Bot. 96(5): 1041-1049.

FRANK D. 2008. The unknown stays mostly unseen. Not note dindigenous taxa of the genera Pteridium and Urtica. Mitt. Florist. Kart. Sachsen-Anhalt (Halle) 13: 29-40.

Halarewicz A. \& Koszelnik-Leszek A. 2007. Wpływ siedliska na rozwój i skład chemiczny orlicy pospolitej Pteridium aquilinum (L.) Kuhn. Roczn. Glebozn. LVIII (12): 24-32.

Harmaja H. 1990. Suomessa on kahdenlaista sananjalkaa. [Two races of bracken (Pteridium aquilinum) in Finland]. Lutukka 6: 15-18.

Gureyeva I. I. \& Page C. N. 2005. Towards the problem of the bracken taxonomy in Siberia - Systematic notes on the materials of the P. N. Krylov Herbarium of Tomsk State University 95: 18-29 (Russian, with very short English summary).

Gureyeva I. I. \& Page C. N. 2008a. The Genus Pteridium (Hypolepidaceae) in the Northern Eurasia. Botanicheskiy Zhurnal [Botanical Journal] 93(6): 915-934 (in Russian with English summary).

Gureyeva I. I. \& Page C. N. 2008b. The fern genus Pteridium in a trans Euro-Siberian perspective - a morphological synthesis. In: S. C. Verma, S. P. Khullar \& H. K. Cheema (eds.). Perspectives in Pteridophytes, pp. 243-254. Bishen Singh Mahendra Pal Singh, Dehradun, India.

Gureyeva I. I. \& Page C. N. 2015. Taxonomical and morphological diversity of Pteridium in Northern Eurasia.
Intern. Conferrence on Lycophyte \& Fern research. Smithsonian Institution \& United State Botanic Garden. 'Next generation to pteridology' Washington 1-5.06.2015. p. 10.

Karlsson T. 2000. Pteridium. In: Flora Nordica, vol. 1, pp. 43-47. Royal Swedish Academy of Sciences Stockholm.

KLeKOwSKi E. J. JR. 1972. Evidence against genetic self-incompatibility in the homosporous fern Pteridium aquilinum. Evolution 26: 66-73.

Mirek Z., PięKoś-Mirkowa H., Zając A. \& Zając M. 2002. Flowering plants and pteridophytes of Poland. A checklist. In: Z. MireK (ed.). Biodiversity of Poland, 1, 442 pp. W. Szafer Institute of Botany, Polish Academy of Sciences, Kraków.

PAge C. N. 1976. The taxonomy and phytogeography of bracken - a review. Bot. J. Linn. Soc. 73: 1-34.

Page C. N. 1986. The strategies of bracken as a permanent ecological opportunist. In: R. T. SмITH \& J. A. TAYLOR (eds.). Ecology, land use and control technology. Parthenon Publ. Carnforth. UK.

Page C. N. 1989. Three subspecies of bracken, Pteridium aquilinum (L.) Kuhn in Britain. Watsonia 17: 429-434.

Page C. N. 1997. The Ferns of Britain and Ireland, ed. 2. Cambridge University Press: Cambridge.

Page C. N. \& Mill R. R. 1995a. Scottish bracken (Pteridium): new taxa and a new combination. Bot. J. Scotl. 47: 139-140.

Page C. N. \& Mill R. R. 1995b. The taxa of Scottish bracken in a European perspective. Bot. J. Scotl. 47: 229-247. 
Petřík P., NeuhäUslová Z. \& SÁdlo J. 2009. Pteridietum aquilini Jouanne et Chouard 1929. In: M. CHYTRÝ (ed.). Vegetace České republiky, 2, Ruderální, plevelová, skalní a sut'ová vegetace (Vegetation of the Czech Republic), 2, Ruderal, weed, rock and scree vegetation), pp. 400-402. Academia, Praha (in Czech).

Rumsey F. J., Sheffield E. \& Haufler C. H. 1991. A reassessment of Pteridium aquilinum (L.) Kuhn in Britain. Watsonia 18: 297-301.

RutKowski L. 2004. Klucz do oznaczania roślin naczyniowych Polski niżowej. Wyd. II, popr. i unowocześnione, 814 pp. Wyd. Nauk. PWN, Warszawa.

Shorina N. I. \& Perestronina O. N. 2000. Taxonomic studies on Russian bracken. I. Taxonomy of Pteridium in territories of European Russia, Crimea and Caucasus. In: J. A. TAYLOR \& R. T. Sмith (eds.). Brackenfern: Toxicity, Biology and Control. Manchester 1999. - IBG Spec. Publ. (Aberyswyth) 4: 48-51.

StatSoft 2003. https://www.statsoft.pl

StefańSKA-KrZACZeK E. 2013. Pteridoflora gospodarczych borów sosnowych na siedliskach świeżych w Borach Dolnośląskich. Acta Bot. Silesiaca 9: 121-134.

Thomson J. A. 2004. Towards a taxonomic revision of Pteridium (Dennstaedtiaceae). Telopea 10(4): 793-803.

Thomson J. A. 2008. Morphotype a conflicting taxonomies in Pteridium (Dennstaedtiaceae: Pteridophyta). Fern Gaz. 18(3): 101-109.

Thomson J. A., Mickel J. T. \& Mehltreter K. 2004. Taxonomic status and relationship of bracken ferns (Pteridum: Dennstaedtiaceae) of Laurasian affinity in Central and North America. Bot. J. Linn. Soc. 157: 1-17.
Tikhomirov V. N. 2009. Morphological variability of Pteridium (Hypolepidaceae) in Belarus. Bielorusskij Gosudarstwiennyj Universitiet, Minsk.

Tryon R. M. 1941. A revision of the genus Pteridium. Rhodora 43: 1-31, 37-67.

Washeka O. V. \& Bezsmertna O. O. 2012. Ferns Atlas of Ukrainian Flora. 160 pp. Kyiv (in Ukrainian).

Wolf P. G., Sheffield E., Thomson J. A. \& Sinclair R. B. 1995. Bracken taxa in Britain. A molecular analysis. In R. T. SMith \& J. A. TAYLOR (eds.). Bracken. An environmental issue, pp. 16-20. University of Leeds, UK.

Wolf P. G., Rowe C. A., Kinosian S. P., Der J. P., Lockhart P. J., Sheperd L. D., McLeanchan P. A. \& Thomson J. A. 2019. Worldwide relationships in the fern genus Pteridium (bracken) based on nuclear genome markers. Am. J. Bot. 106(10): 1365-1376.

Zenkteler E., Jędrzejczyk I. \& Melosik I. 2015. Pteridum aquilinum - czy w Polsce występująjego podgatunki? IV Warsztaty Sekcji Pteridologicznej PTB, "Rodzaj Pteridium w Polsce”. Poznań, 09.2015.

Zenkteler E., Nowak O., Jędrzejczyk I. \& Melosik I. 2016. Discrimination between Pteridium aquilinum (L.) Kuhn and $P$. pinetorum C. N. Page \& R. R. Mill. (Dennstaedtiaceae) based on morphometric analysis of Polish samples. Streszcz. referatów i plakatów 57. Zjazdu PTB, 23.06-3.07.2016. Lublin, p. 248.

Zhou S., Dong W., Chen X., Zhang X., Wen J. \& Schneider H. 2014. How many species of bracken (Pteridium) are there? Assessing the Chinese brackens using molecular evidence. Taxon 63(3): 509-521. https://doi. org/10.12705/633.9 